\title{
Specific emissions analysis for a combustion engine in dynamometer operation in relation to the thermal state of the exhaust gas aftertreatment systems in a modified NRSC test
}

\author{
Jerzy Merkisz ${ }^{1, *}$, and Maciej Siedlecki ${ }^{1}$ \\ ${ }^{1}$ Poznan University of Technology, Faculty of Machines and Transport, ul. Piotrowo 3, 60-965 Poznan, Poland
}

\begin{abstract}
Exhaust gas aftertreatment systems have been present in motor vehicles for decades and have contributed to reducing their impact on the environment and people. Most of them for oxidation or reduction of harmful emissions of particulates and fumes require a certain temperature to be reached that changes with the exhaust temperature, i.e. the points of engine operation. The article describes the effect of oxidation reactor and particulate filter temperatures on specific emissions of gaseous compounds and particulate matter during the modified NRSC engine test. Before the first measurement cycle, the engine was idling, before the second measurement cycle, the exhaust system was heated with exhaust gases at full engine load until passive regeneration of the particle filter occurred (noticeable decrease in instantaneous particle concentration).
\end{abstract}

\section{Introduction}

The process of burning fuel in engines causes the formation of a number of harmful compounds. The products of complete and total combustion include carbon dioxide and water vapor; however, nitrogen oxides, carbon monoxide, hydrocarbons, solid particles and others are also produced by imperfections in this process. For motor vehicles, they have been limited by the Euro emission standards since 1992 [1]. The legal emission limits are further reduced with the introduction of subsequent emission standards. In spite of the technological advances in engine construction and better control of the combustion process in the internal combustion engine by using advanced electronic fuel injection systems, it is not possible to meet these standards without the use of in-engine and exhaust aftertreatment systems $[2,3]$.

The latter have been used in vehicles for decades, practically in all vehicles with an internal combustion engine. The basic element for SI engines is a three-way catalytic reactor, and for $\mathrm{CI}$ engines, due to different air excess coefficient values, oxidation reactor (DOC) [4]. Currently, diesel particulate filters (DPFs) and selective catalytic reduction are common in vehicles with CI engines $[5,6]$. This is also the first solution currently being applied to vehicles with spark ignition engines due to the introduction of further limits for specific emission of harmful exhaust gases [7,8].

These systems require a certain temperature to operate correctly, depending on the construction and materials used as the substrate, the intermediate layer and the catalytic layer. An enriched fuel blend is usually used in the engine during the cold start, which further enhances its emissivity in order to warm up both the engine and the exhaust system faster. This temperature mainly depends on the operating point of the engine, and more specifically its load [9]. This means, however, that the first few moments after engine start the emissions from the engine are significant and continue until the set temperature has been reached by the exhaust aftertreatment systems and by the internal combustion engine itself $[10,11]$.

At present, the engine design companies are looking for the most environmentally friendly solutions. Virtually every manufacturer of passenger vehicles currently offers hybrid vehicles combining the advantages of an internal combustion engine and a large group also offer full electric vehicles. Despite the gradual replacement of the classic diesel engine, it still remains the main source of propulsion for the vehicles currently in operation, and this will clearly not change in the coming years $[12,13]$. Only further improvement in fuel consumption reduction and associated emissions of harmful compounds is left to the engine designers.

In order to counteract the effects of the under-heated propulsion system operation in today's vehicles, heating devices are used, which accelerate the process of reaching the operating temperature of both the exhaust gas aftertreatment systems and other systems like the lambda probe [14].

This article examines the effect of pre-heating the engine exhaust aftertreatment system on the emission of toxic compounds scaled to the unit of generated energy.

Corresponding author: jerzy.merkisz@.put.poznan.pl 


\section{Research methodology}

The tested CI engine had a displacement of $1.3 \mathrm{dm}^{3}$ (Fig. 1). The engine was approved with the EURO 4 standard, but for the requirements of the test the factory standard DOC was removed, and the EGR valve was sealed shut. The basic engine technical data has been listed in Tab. 1 .

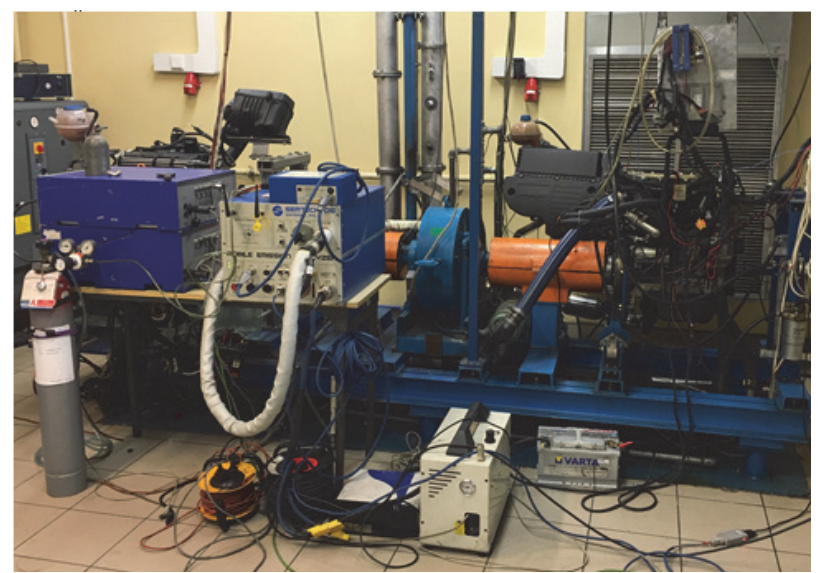

Fig. 1. The tested engine mounted on an engine dynamometer.

The tests were performed on the AUTOMEX engine dynamometer system using an electric brake. Brake information is listed in tab. 2 . The engine operating point is set with a high accuracy on the control cabinet (Fig. 2) in each measurement case.

Table 1. Basic information about combustion engine.

\begin{tabular}{|l|c|}
\hline $\begin{array}{l}\text { Number of cylinders / } \\
\text { displacement }\end{array}$ & 4, in-line $/ 1.3 \mathrm{dm}^{3}$ \\
\hline Bore / stroke & $70 \mathrm{~mm} / 86 \mathrm{~mm}$ \\
\hline Maximum power & $52 \mathrm{~kW}$ at $4000 \mathrm{rpm}$ \\
\hline Maximum torque & $180 \mathrm{Nm}$ at $1750 \mathrm{rpm}$ \\
\hline Compression ratio & $18,0: 1$ \\
\hline Supercharging & Turbocharger (FGT) \\
\hline Exhaust emission standard & Euro IV \\
\hline
\end{tabular}

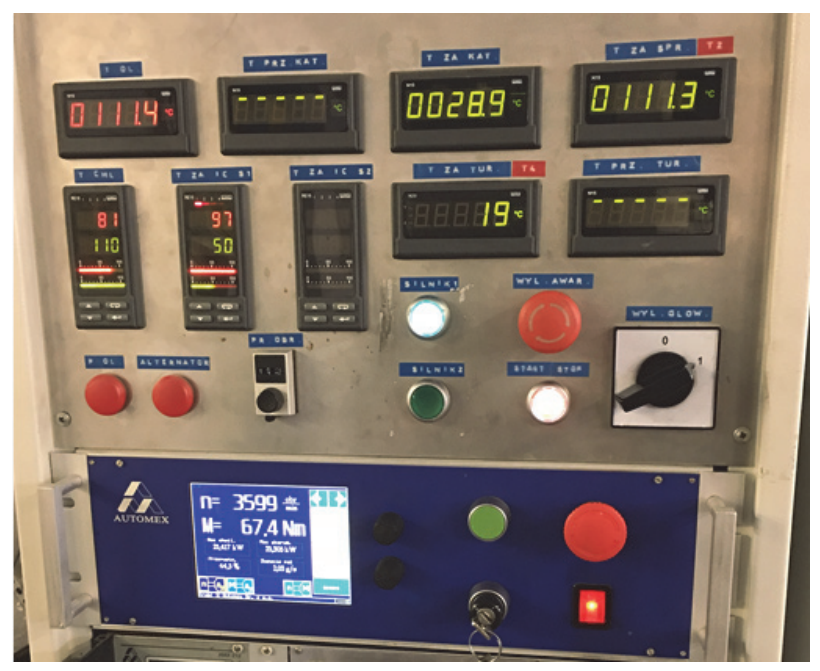

Fig. 2. Control cabinet used in research.
Table 2. Engine dynamometer technical data.

\begin{tabular}{|l|c|}
\hline Brake type & AMX-210/100 \\
\hline Maximum power & $100 \mathrm{~kW}$ \\
\hline Maximum engine speed & $10,000 \mathrm{rpm}$ \\
\hline Maximum torque & $240 \mathrm{Nm}$ \\
\hline Direction of rotation & Any \\
\hline
\end{tabular}

The exhaust system was retrofitted in DOC and DPF (Fig. 3). These elements are placed exactly in the exhaust gas flow axis and additionally sealed with a high temperature paste and then screwed together. Their airtightness was checked before the start of each test cycle.

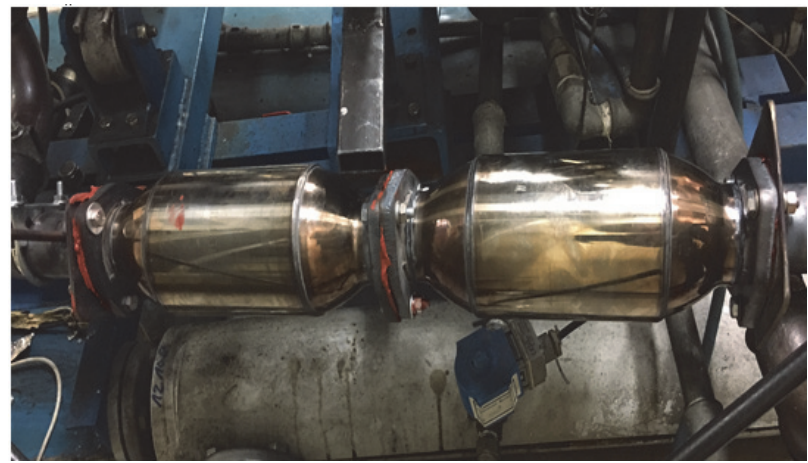

Fig. 3. The exhaust aftertreatment system used in the engine tests $(\mathrm{DOC}+\mathrm{DPF})$.

The elements were brand new before the measurement, both of which used metallic substrates in the form of folded sheet metal with applied catalytic layers. The DOC and DPF systems are presented in Fig. 4 and 5.

The assessment of the exhaust emissions level was performed with the PEMS equipment measuring the concentration of the exhaust gas components. In the work described in the paper, SEMTECH DS - a portable exhaust emissions analyzer manufactured by Sensors Inc. was used (Fig. 6).

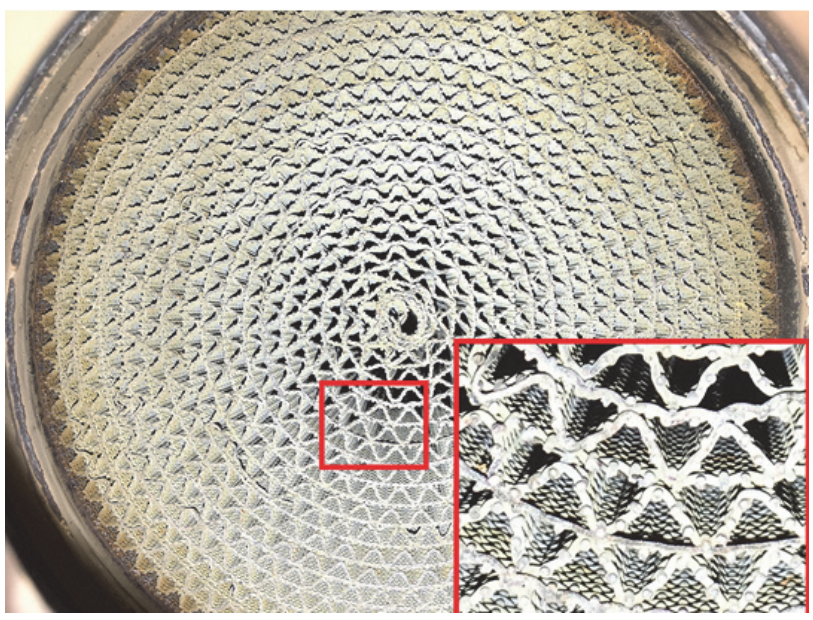

Fig. 4. The inside of the DOC. 


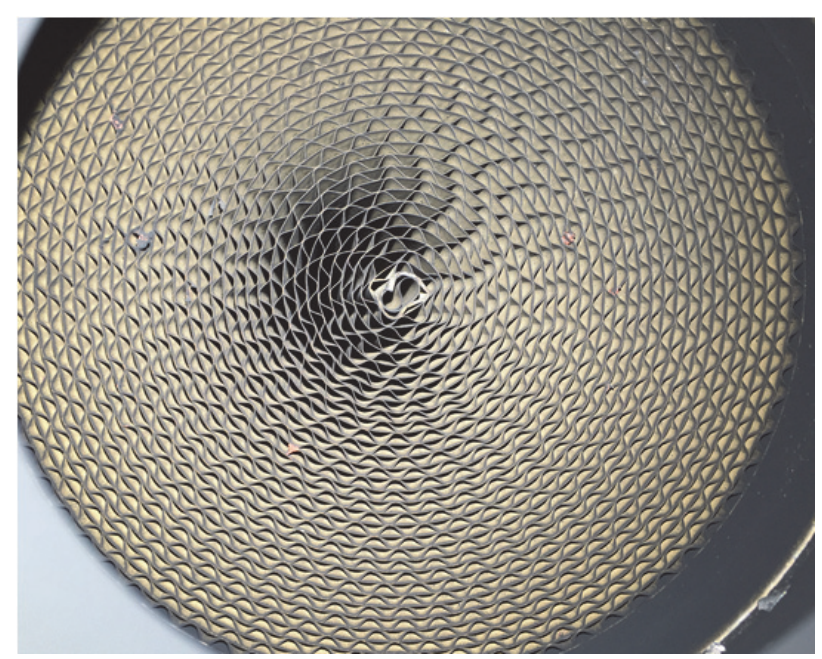

Fig. 5. The inside of the DPF.

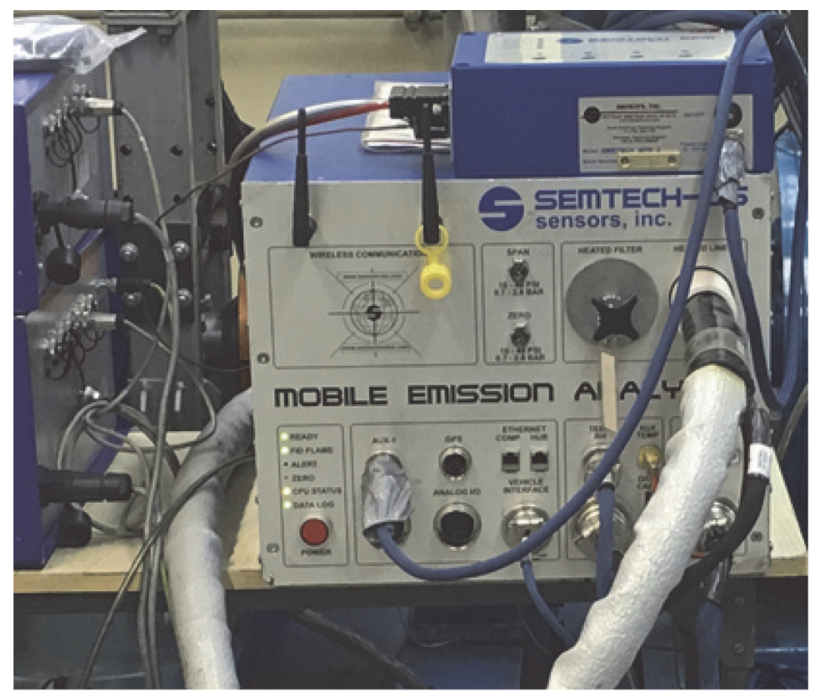

Fig. 6. SEMTECH DS analyzer by Sensors Inc.

The entire volume of the exhaust gas from the exhaust system was sent to the mass flow meter and then through a measurement probe (maintaining the temperature of $191{ }^{\circ} \mathrm{C}$ ) to the analyzer. The device filtered the exhaust gas to separate the particulate matter (PM). In the next step, the system measured the concentration of hydrocarbons in a FID (Flame Ionization Detector) (Fig. 7). The exhaust gas was then chilled to the temperature of $4{ }^{\circ} \mathrm{C}$ and the concentrations of nitrogen oxides (NDUV, Non-Dispersive UltraViolet), carbon monoxide/carbon dioxide (NDIR, NonDispersive Infrared) and oxygen (electrochemical analyzer) were measured. The device is compatible with the vehicle's on-board diagnostic system (recording of the operating parameters - engine speed and load) and GPS (latitude and longitude for determining the vehicle speed), which was not used in this research.

The authors used MSS (Micro Soot Sensor) by AVL (Fig. 8a) for the measurement of particulate matter. The device uses laser light dispersion triggered by particulate matter contained in the exhaust gas. AVL MSS can determine the real time concentration of PM in the exhaust gas.

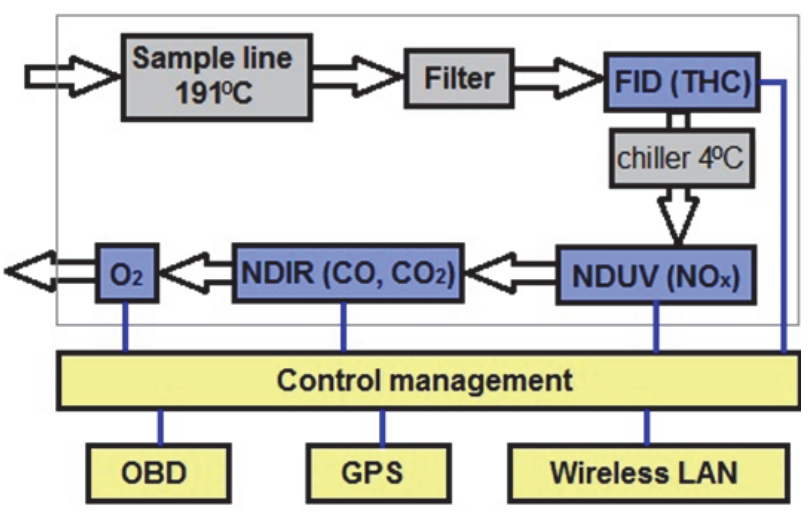

Fig. 7. Diagram of the portable exhaust emissions analyzer (SEMTECH DS) with the exhaust gas flow (=) and electrical connections (---) marked [15].

The number of the particles were measured by EEPS TSI (Fig 8b). In this device, the solid particles get an electrical charge and then they reach the electrodes, the larger the particle the further the electrode reached.

a)

b)

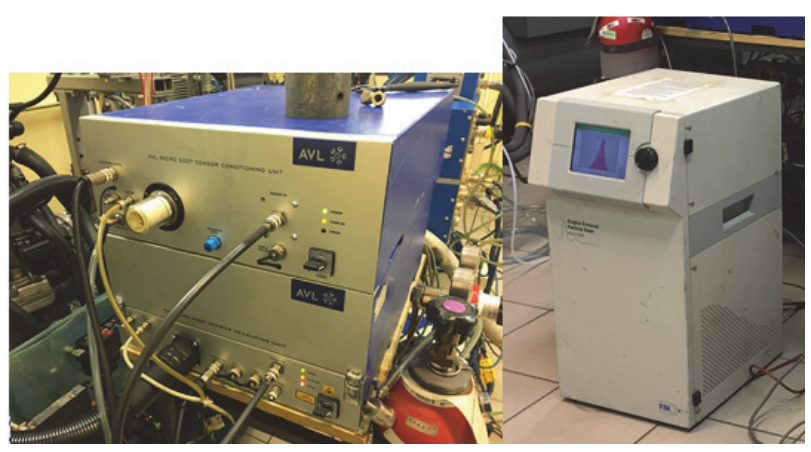

Fig. 8. View of the: a) AVL Micro Soot Sensor, b) TSI EEPS.

At the start of the measurements, the analyzers were calibrated with reference gases according to the manufacturer's guidelines. This process consists of delivering a strictly defined gas composition to the gas analyzers. This operation is repeated for several gas canisters, thereby restoring the original operating characteristics of the device.

In addition, before the measurements were made, the ambient air was used to determine the data offset. The device did not report any operational errors when performing measurements.

Engine operating points were determined in accordance with a modified NRSC test. This is a stationary test introduced with Directive 97/68/EC in 1997. This directive has had numerous updates, but the test is still used today to measure the emissions of harmful gases contained in exhaust gases in non-road vehicle tests. This choice was made because it is a stationary test that can be performed on a test bench. Modification compared to the original test consisted of changing the operating points to make them more in-line with the real conditions of non-road vehicles operation [16]. The changes involved reducing the maximum engine load while increasing the load at points where it was low. This change was made on the basis of a 
comprehensive analysis of operating points of NRMM vehicle engines in actual operation. The weight of each point's contribution to the total value was also determined based on the time that the engine spent operating in given point while in actual operating conditions. The operating points are shown in table 3 and have been graphically represented in Fig. 9.

Table 3. Operating points measured for the tested engine [16].

\begin{tabular}{|c|c|c|c|}
\hline $\begin{array}{c}\text { Operating } \\
\text { point }\end{array}$ & $\begin{array}{c}\text { Crankshaft rotational } \\
\text { speed [rpm] }\end{array}$ & $\begin{array}{c}\text { Load } \\
{[\mathrm{Nm}]}\end{array}$ & $\begin{array}{c}\text { Weight } \\
\text { average }\end{array}$ \\
\hline 1 & 2400 & 148,5 & 0.15 \\
\hline 2 & 2400 & 107 & 0.2 \\
\hline 3 & 2400 & 66 & 0.2 \\
\hline 4 & 3600 & 97,5 & 0.1 \\
\hline 5 & 3600 & 67 & 0.1 \\
\hline 6 & 3600 & 36,6 & 0.1 \\
\hline 7 & 770 & 3,3 & 0.15 \\
\hline
\end{tabular}

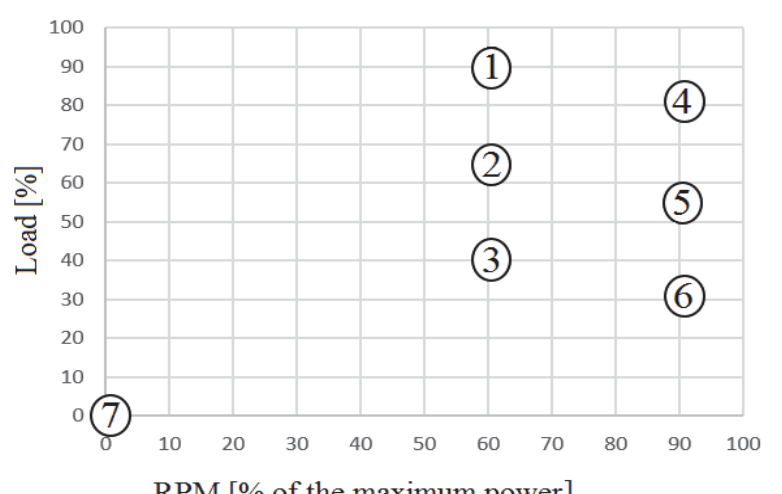

Fig. 9. Operating points for the tested engine [16].

The engine worked for 60 seconds at each operating point, and the shift between the points was dependent on the filter inlet and outlet temperatures. Measurement was taken when the temperature has not changed by more than $1{ }^{\circ} \mathrm{C}$ for 10 seconds. The entire cycle was performed three times in each case to eliminate any random errors. The warm up of the system consisted in maintaining the engine operating point so that the filter temperature was above $400{ }^{\circ} \mathrm{C}$ for a period of 10 minutes and during that time a passive regeneration of the DPF occurred. This process involves the use of nitrogen dioxide which, at elevated temperatures after contact with the solids, causes them to oxidize and as a result, purge the particles that accumulated in the filter. The system was considered cold when the engine worked for 10 minutes at idle before measurements. In this case, the approximate temperature of the exhaust aftertreatment system was 140 degrees centigrade.

\section{Results and analysis}

The measured concentrations were used in calculations on a spreadsheet to determine the value of specific emissions. Both emission concentration and instantaneous power measurements were averaged over the entire measuring cycle lasting 60 seconds according to the weight of the individual operating points. The results of the emissivity of the individual compounds were presented in table and mean values were presented graphically. Due to the tests performed on the engine dynamometer, all the values reported were calculated as per unit work expressed in $\mathrm{kWh}$. Taking into account the output value, i.e. the lack of exhaust aftertreatment systems as a benchmark, the result was divided by these values and converted into percentages.

Carbon monoxide emission research results are presented in Tab. 4 and the average of the test in Fig. 10. All values are given with a background reference, which is $100 \%$.

Table 4. Results of the carbon monoxide emission at specific points of engine operation.

\begin{tabular}{|c|c|c|c|c|c|}
\hline $\begin{array}{c}\text { Point } \\
\text { no. }\end{array}$ & $\begin{array}{c}\text { Crankshaft } \\
\text { rotational } \\
\text { speed }[\mathrm{rpm}]\end{array}$ & $\begin{array}{c}\text { Load } \\
{[\mathrm{Nm}]}\end{array}$ & $\begin{array}{c}\text { W/o after- } \\
\text { treatment } \\
{[\mathrm{g} / \mathrm{kWh}]}\end{array}$ & $\begin{array}{c}\text { Cold after- } \\
\text { treatment } \\
{[\mathrm{g} / \mathrm{kWh}]}\end{array}$ & $\begin{array}{c}\text { Hot after- } \\
\text { treatment } \\
{[\mathrm{g} / \mathrm{kWh}]}\end{array}$ \\
\hline 1 & 2400 & 148.5 & 0.18 & 0.18 & 0.14 \\
\hline 2 & 2400 & 107 & 0.28 & 0.31 & 0.03 \\
\hline 3 & 2400 & 66 & 0.47 & 0.39 & 0.37 \\
\hline 4 & 3600 & 97.5 & 0.29 & 0.21 & 0.21 \\
\hline 5 & 3600 & 67 & 0.38 & 0.36 & 0.35 \\
\hline 6 & 3600 & 36.6 & 1.25 & 0.53 & 0.57 \\
\hline 7 & 770 & 3.3 & 5.64 & 3.38 & 3.38 \\
\hline
\end{tabular}

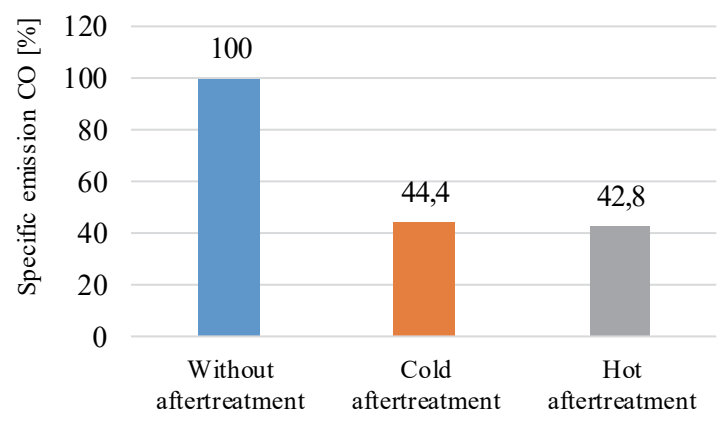

Fig. 10. Relative specific $\mathrm{CO}$ emissions for the cold and hot exhaust gas treatment system.

For carbon monoxide there is a noticeable reduction in emissivity for both cold and hot systems. The carbon monoxide emissions is almost halved and demonstrates high efficiency of the aftertreatment system despite various engine loads during the test. For the hot exhaust system, a slightly worse result was obtained due to the high temperature of the DOC mounted before the DPF. No significant differences in emissivity for cold and hot systems were found in the results between the individual operating points.

The reduction in emissions was mainly due to the DOC. The greatest differences between systems at different temperature states can be seen for the first measurement point, which makes it possible to consider the heating of the system as an effective solution for reducing emissions. At the later operating points, the 
relative differences were very small. Hydrocarbon emissions are listed in Tab. 5 and shown in Fig. 11.

Table 5. Results of specific hydrocarbon emissions at different points of engine operation.

\begin{tabular}{|c|c|c|c|c|c|}
\hline $\begin{array}{c}\text { Point } \\
\text { no. }\end{array}$ & $\begin{array}{c}\text { Crankshaft } \\
\text { rotational } \\
\text { speed }[\mathrm{rpm}]\end{array}$ & $\begin{array}{c}\text { Load } \\
{[\mathrm{Nm}]}\end{array}$ & $\begin{array}{c}\text { W/o after- } \\
\text { treatment } \\
{[\mathrm{g} / \mathrm{kWh}]}\end{array}$ & $\begin{array}{c}\text { Cold after- } \\
\text { treatment } \\
{[\mathrm{g} / \mathrm{kWh}]}\end{array}$ & $\begin{array}{c}\text { Hot after- } \\
\text { treatment } \\
{[\mathrm{g} / \mathrm{kWh}]}\end{array}$ \\
\hline 1 & 2400 & 148.5 & 0.18 & 0.18 & 0.02 \\
\hline 2 & 2400 & 107 & 0.28 & 0.31 & 0.03 \\
\hline 3 & 2400 & 66 & 0.47 & 0.39 & 0.06 \\
\hline 4 & 3600 & 97.5 & 0.29 & 0.21 & 0.21 \\
\hline 5 & 3600 & 67 & 0.38 & 0.36 & 0.35 \\
\hline 6 & 3600 & 36.6 & 1.25 & 0.53 & 0.57 \\
\hline 7 & 770 & 3.3 & 5.64 & 3.38 & 3.38 \\
\hline
\end{tabular}

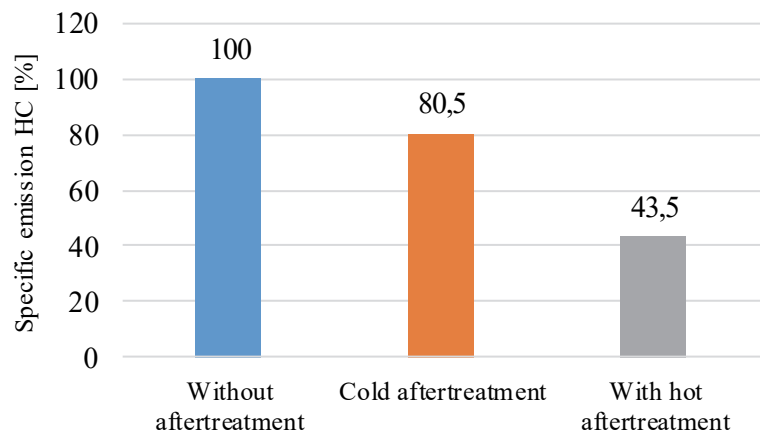

Fig. 11. Relative specific $\mathrm{HC}$ emissions for the cold and hot exhaust system.

In the case of hydrocarbons, the cold system reduces their emissions by $20 \%$ over the measurement without exhaust gas aftertreatment systems. After warming up, this value is increased almost twice, to $43 \%$ of the initial value. Unlike in the case of carbon monoxide, there can be a significant positive influence of heating the system on its effectiveness. Again, the impact of the particle filter application is rather small and the oxidation reactor has significant impact on the change in emissivity. The biggest differences are seen for the first three operating points where the success of the hot system is $90 \%$. Results of nitrogen oxide emission tests are presented in Tab. 6 and the mean of the measurements in Fig. 12.

Table 6. Specific emission results for nitrogen oxides at individual engine operating points.

\begin{tabular}{|c|c|c|c|c|c|}
\hline $\begin{array}{c}\text { Point } \\
\text { no. }\end{array}$ & $\begin{array}{c}\text { Crankshaft } \\
\text { rotational } \\
\text { speed }[\mathrm{rpm}]\end{array}$ & $\begin{array}{c}\text { Load } \\
{[\mathrm{Nm}]}\end{array}$ & $\begin{array}{c}\text { W/o after- } \\
\text { treatment } \\
{[\mathrm{g} / \mathrm{kWh}]}\end{array}$ & $\begin{array}{c}\text { Cold after- } \\
\text { treatment } \\
{[\mathrm{g} / \mathrm{kWh}]}\end{array}$ & $\begin{array}{c}\text { Hot after- } \\
\text { treatment } \\
{[\mathrm{g} / \mathrm{kWh}]}\end{array}$ \\
\hline 1 & 2400 & 148.5 & 7.18 & 7.20 & 7.80 \\
\hline 2 & 2400 & 107 & 8.04 & 8.26 & 10.86 \\
\hline 3 & 2400 & 66 & 8.38 & 16.20 & 14.30 \\
\hline 4 & 3600 & 97.5 & 9.66 & 10.01 & 9.55 \\
\hline 5 & 3600 & 67 & 11.33 & 13.02 & 12.88 \\
\hline 6 & 3600 & 36.6 & 14.21 & 16.16 & 15.86 \\
\hline 7 & 770 & 3.3 & 45.87 & 49.26 & 43.62 \\
\hline
\end{tabular}

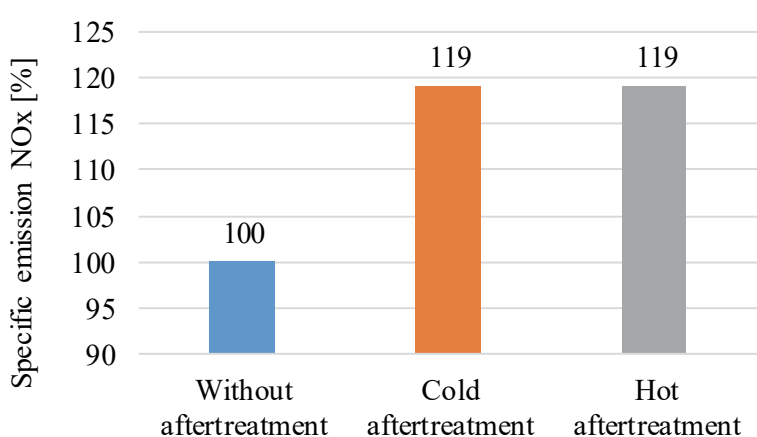

Fig. 12. Relative specific $\mathrm{NO}_{\mathrm{x}}$ emissions for the cold and hot exhaust system.

Emissions of nitrogen oxides are increased when using exhaust aftertreatment systems. The increase in both cold and hot cases amounted to approximately 19\%. This increase was most apparent in the medium load range (operating points 3 and 6). This can be due to the high temperature inside the DOC despite the temperature of the exhaust gas. Again the increased emissions are affected by the use of an oxidation reactor where NO is converted to $\mathrm{NO}_{2}$ for example, which is used for passive filter regeneration. For this reason, it was decided that the increase in $\mathrm{NO}_{2}$ emissions must be analyzed separately (Tab. 7 and Fig. 13).

Table 7. Results of the specific emission of nitrogen dioxide at individual points of engine operation.

\begin{tabular}{|c|c|c|c|c|c|}
\hline $\begin{array}{c}\text { Point } \\
\text { no. }\end{array}$ & $\begin{array}{c}\text { Crankshaft } \\
\text { rotational } \\
\text { speed }[\mathrm{rpm}]\end{array}$ & $\begin{array}{c}\text { Load } \\
{[\mathrm{Nm}]}\end{array}$ & $\begin{array}{c}\text { W/o after- } \\
\text { treatment } \\
{[\mathrm{g} / \mathrm{kWh}]}\end{array}$ & $\begin{array}{c}\text { Cold after- } \\
\text { treatment } \\
{[\mathrm{g} / \mathrm{kWh}]}\end{array}$ & $\begin{array}{c}\text { Hot after- } \\
\text { treatment } \\
{[\mathrm{g} / \mathrm{kWh}]}\end{array}$ \\
\hline 1 & 2400 & 148.5 & 0.18 & 2.66 & 1.79 \\
\hline 2 & 2400 & 107 & 0.20 & 3.99 & 2.55 \\
\hline 3 & 2400 & 66 & 0.30 & 6.00 & 5.44 \\
\hline 4 & 3600 & 97.5 & 0.48 & 3.18 & 2.96 \\
\hline 5 & 3600 & 67 & 0.71 & 4.59 & 4.28 \\
\hline 6 & 3600 & 36.6 & 0.65 & 4.46 & 3.68 \\
\hline 7 & 770 & 3.3 & 8.65 & 11.13 & 12.70 \\
\hline
\end{tabular}

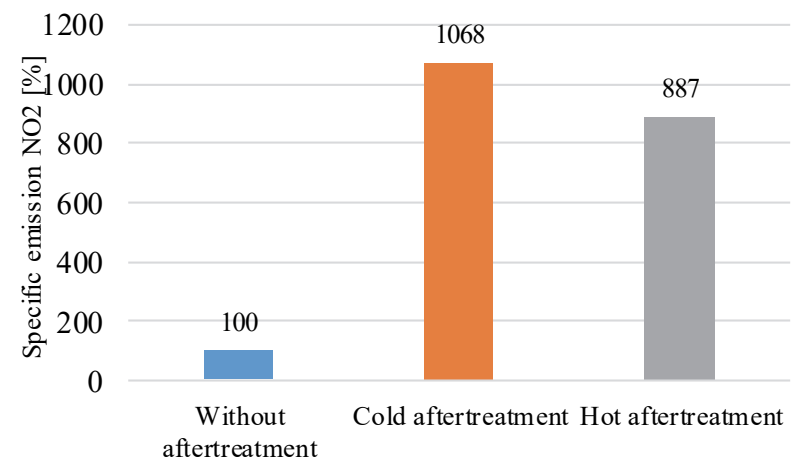

Fig. 13. Relative specific $\mathrm{NO}_{2}$ emissions for the cold and hot exhaust system.

The results clearly show a high NO oxidation share in $\mathrm{NO}_{2}$ generation. Especially at maximum loads, the exhaust aftertreatment system increases $\mathrm{NO}_{2}$ emissions 
by as much as twenty times. The average of the entire test is more than a tenfold increase in emissions for the cold system and nearly nine fold for the hot system. The cold system produces much more nitrogen oxide IV for the first three measurement points. Emission results for PM are found in Tab. 8 and Fig. 14.

Table 8. Specific PM emission results at individual engine operating points.

\begin{tabular}{|c|c|c|c|c|c|}
\hline Point no & $\begin{array}{c}\text { Crankshaft } \\
\text { rotational } \\
\text { speed }[\mathrm{rpm}]\end{array}$ & $\begin{array}{c}\text { Load } \\
{[\mathrm{Nm}]}\end{array}$ & $\begin{array}{c}\text { W/o after- } \\
\text { treatment } \\
{[\mathrm{g} / \mathrm{kWh}]}\end{array}$ & $\begin{array}{c}\text { Cold after- } \\
\text { treatment } \\
{[\mathrm{g} / \mathrm{kWh}]}\end{array}$ & $\begin{array}{c}\text { Hot after- } \\
\text { treatment } \\
{[\mathrm{g} / \mathrm{kWh}]}\end{array}$ \\
\hline 1 & 2400 & 148.5 & 0.76 & 0.53 & 0.56 \\
\hline 2 & 2400 & 107 & 0.15 & 0.13 & 0.19 \\
\hline 3 & 2400 & 66 & 0.12 & 0.11 & 0.13 \\
\hline 4 & 3600 & 97.5 & 0.91 & 0.64 & 0.72 \\
\hline 5 & 3600 & 67 & 0.40 & 0.25 & 0.27 \\
\hline 6 & 3600 & 36.6 & 0.41 & 0.28 & 0.31 \\
\hline 7 & 770 & 3.3 & 2.54 & 2.51 & 2.62 \\
\hline
\end{tabular}

In the case of particulate matter, the use of additional exhaust aftertreatment systems contributed to a $16 \%$ and a $10 \%$ decrease in particle mass emissions, for the hot and cold systems respectively. This difference was quite small, probably due to the considerable distance of the filter from the exhaust manifold and consequently its temperature. The second reason may be the lack of the control system adjustment to the presence of a particulate filter. The cold system proved to be more effective in oxidizing the particles.

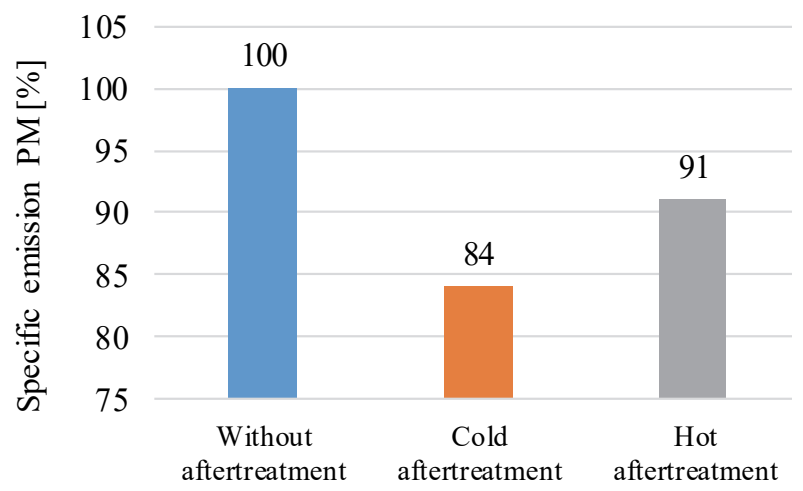

Fig. 14. Relative specific emission of PM for the cold and hot exhaust gas aftertreatment system.

This could be due to the increased amount of nitrogen oxide IV required for passive regeneration. The biggest differences were observed for the highest engine loads. For points with little or no load, the differences are minimal, which indicates a very low efficiency of the aftertreatment system. The cold system results in reduced PM emissions at all measuring points. The final component tested was the number of particles, the results of which are shown in Tab. 9 and Fig 15.
Table 9. Specific PN emission results at individual engine operating points.

\begin{tabular}{|c|c|c|c|c|c|}
\hline $\begin{array}{c}\text { Point } \\
\text { no. }\end{array}$ & $\begin{array}{c}\text { Crankshaft } \\
\text { rotational } \\
\text { speed [rpm }]\end{array}$ & $\begin{array}{c}\text { Load } \\
{[\mathrm{Nm}]}\end{array}$ & $\begin{array}{c}\text { W/o after- } \\
\text { treatment } \\
{[\mathrm{g} / \mathrm{kWh}]}\end{array}$ & $\begin{array}{c}\text { Cold after- } \\
\text { treatment } \\
{[\mathrm{g} / \mathrm{kWh}]}\end{array}$ & $\begin{array}{c}\text { Hot after- } \\
\text { treatment } \\
{[\mathrm{g} / \mathrm{kWh}]}\end{array}$ \\
\hline 1 & 2400 & 148.5 & $6.73 \mathrm{E}+11$ & $5.03 \mathrm{E}+11$ & $7.15 \mathrm{E}+11$ \\
\hline 2 & 2400 & 107 & $3.59 \mathrm{E}+12$ & $1.03 \mathrm{E}+12$ & $1.27 \mathrm{E}+12$ \\
\hline 3 & 2400 & 66 & $2.58 \mathrm{E}+12$ & $1.26 \mathrm{E}+12$ & $1.11 \mathrm{E}+12$ \\
\hline 4 & 3600 & 97.5 & $1.35 \mathrm{E}+12$ & $1.23 \mathrm{E}+12$ & $1.05 \mathrm{E}+12$ \\
\hline 5 & 3600 & 67 & $4.47 \mathrm{E}+12$ & $1.26 \mathrm{E}+12$ & $1.40 \mathrm{E}+12$ \\
\hline 6 & 3600 & 36.6 & $5.89 \mathrm{E}+12$ & $1.59 \mathrm{E}+12$ & $1.69 \mathrm{E}+12$ \\
\hline 7 & 770 & 3.3 & $6.67 \mathrm{E}+12$ & $5.40 \mathrm{E}+12$ & $5.67 \mathrm{E}+12$ \\
\hline
\end{tabular}

Unlike small differences in particulate mass, the particle number is reduced by nearly half due to the presence of the exhausr gas aftertreatment system, which would indicate that the DPF has a high trapping efficiency for the smallest sized particles. Just like in the PM evaluation, the cold system is more effective, although the difference is less significant and mainly affects the first two operating points. This would indicate that this system worked with lower efficiency after being heated up before use in terms of particle number emissions.

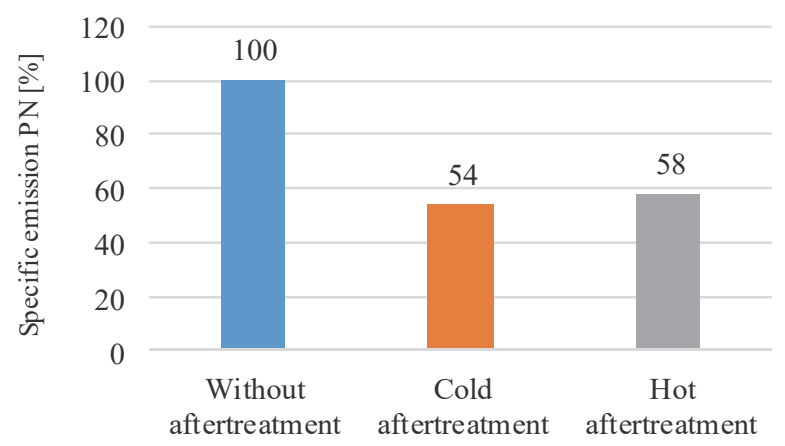

Fig. 15. Relative specific PN emission for the cold and hot exhaust gas aftertreatment system.

\section{Summary}

The exhaust aftertreatment systems are nowadays indispensable for virtually any vehicle with an internal combustion engine. Without it, strict type approval standards simply cannot be met. However, the test conditions in the laboratory often differ from what happens in real life. Frequent starts of the car engine cause the systems to be underactive and prevents them from operating with satisfactory efficacy in reducing toxicity.

The undertaken research efforts described in the article were concerned with the assessment of the exhaust aftertreatment systems pre-heating influence on the internal combustion engine emissivity, based on the exhaust gas measurements. The use of a Euro IV approved engine in the exhaust emission tests greatly 
influenced the overall emissivity values. Carbon monoxide emission was significantly reduced. A slight reduction in the carbon dioxide was observed as well as in the mass and number of emitted particles. The emission of nitrogen oxides, especially $\mathrm{NO}_{2}$, has been significantly increased. Self-warming of the system has a clear positive effect on the carbon monoxide and hydrocarbon emissions. Nitrogen oxides are not much different, but differences appear in the analysis of the nitrogen oxide VI. More of this compound is emitted from a cold engine. In the case of particles, it is surprising that the cold system reduces both the number and the mass of the particles more effectively than when heating up.

The research was funded by project co-financed by the European Regional Development Fund in the Regional Program - Lubuskie 2020 (contract No. RPLB.01.01.00-080055/16-00).

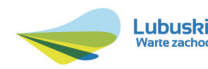

Unia Europejska Europejski Fundusz
Rozwoju Regionalnego

\section{References}

1. M. Bajerlein, P. Fuc, P. Lijewski, L. Rymaniak, A. Ziolkowski, M. Dobrzynski, Combustion Engines 154, 708-715 (2013)

2. J. Merkisz, P. Fuc, P. Lijewski, M. Siedlecki, A. Ziolkowski, IOP Conference Series-Materials Science and Engineering 148, UNSP 012077 (2016), DOI: 10.1088/1757-899X/148/1/012077

3. M. Bajerlein, L. Rymaniak, P. Swiatek, A. Ziolkowski, P. Daszkiewicz, M. Dobrzynski, Experimental and Applied Mechanics 518, 108-113 (2014), DOI: 10.4028/www.scientific.net/AMM.518.108

4. P. Fuc, P. Lijewski, A. Ziolkowski, M. Dobrzynski, Journal of Electronic Materials 46, 3145-3155 (2017)

5. M. Bajerlein, L. Rymaniak, Technika Transportu Szynowego 10, 2773-2782 (2013)

6. P. Fuc, L. Rymaniak, A. Ziółkowski, WIT Transactions on Ecology and the Environment 174, 207-218 (2013)

7. W. Burget, $9^{\text {th }}$ AVL International Commercial Powertrain Conference (2017)

8. R. Jasinski, J. Pielecha, J. Markowski, E3S Web of Conferences 10, UNSP 00030 (2016), DOI: $10.1051 / \mathrm{e} 3$ sconf $/ 20161000030$

9. P. Fuc, J. Merkisz, P. Lijewski, M. Bajerlein, A. Ziolkowski, L. Rymaniak, M. Dobrzynski, Combustion Engines 154, 701-707 (2013)

10. J. Markowski, J. Pielecha, R. Jasinski, T. Kniaziewicz, P. Wirkowski, E3S Web of Conferences 10, UNSP 00140 (2016), DOI: $10.1051 / \mathrm{e} 3$ sconf $/ 20161000140$
11. J. Merkisz, J. Markowski, J. Pielecha, WIT Transactions on Ecology and the Environment 174, 219-230 (2013), DOI: 10.2495/AIR130191

12. J. Merkisz, J. Markowski, J. Pielecha, IEEE Vehicle Power and Propulsion Conference VPPC, 897-902 (2012)

13. J. Merkisz, P. Fuc, P. Lijewski, J. Pielecha, Transportation Research Procedia 14, 3070-3078 (2016), DOI: 10.1016/j.trpro.2016.05.452

14. M. Idzior, M. Bajerlein, P. Lijewski, P. Fuc, Global Science and Technology Forum (Singapore, 2013)

15. Sensors Inc. Emissions Measurement Solutions (Erkrath, 2010)

16. P. Lijewski, Postdoctoral thesis (Poznan, 2013) 